\title{
IMPACT OF REACTOR OPERATION ON SUCCESS OF STRUVITE PRECIPITATION
}

FROM SYNTHETIC LIQUORS

\author{
K. S. LE CORRE ${ }^{1}$, E. VALSAMI-JONES², P. HOBBS 3 , S. A. PARSONS ${ }^{*}$ \\ ${ }^{1}$ Centre for Water Science, Cranfield University, Cranfield MK43 0AL, UK
}

*Tel: +44 (0)1234 754841, Fax: +44 (0)1234 751671

E-mail address: s.a.parsons@cranfield.ac.uk

2 Department of Mineralogy, The Natural History Museum, Cromwell Road, London SW7 5BD,

\section{UK}

3Institute of Grassland and Environmental Research (IGER), North Wyke, Okehampton EX20

$$
\text { 2SB, UK }
$$

\begin{abstract}
A pilot scale reactor was designed and developed to study struvite crystallisation principles. The present work focuses on the possible impact of reactor's operating parameters on struvite characteristics, and evaluates the performances of the process in removing phosphorus. Struvite precipitation from synthetic liquors was investigated under various situations including: $\mathrm{pH}$, magnesium dosing, addition of foreign ions such as calcium and increasing retention time. Small variations of all these parameters were found to have significant effects on struvite crystal characteristics and/or production. For instance, an increase of $\mathrm{pH}$ from 10.0 to 10.5 favoured the formation of $\mathrm{Mg}_{3}\left(\mathrm{PO}_{4}\right)_{2} \cdot 22 \mathrm{H}_{2} \mathrm{O}$ rather than struvite. For molar ratios Ca:Mg above 1:1, calcium ions competed with magnesium to form an amorphous calcium phosphate, hence inhibiting struvite formation. With regards to crystal growth, the process showed some limitations. Indeed, large amounts of fines were produced, and crystal rarely grew over $100 \mu \mathrm{m}$ under optimum conditions. Based on those observations, zeta-potential measurements of struvite crystals were investigated. Results revealed highly negative zeta-potential values for all experiments, indicating that this may be a limitation to struvite tendency for agglomeration.
\end{abstract}

Keywords: Phosphorus removal, struvite production, particle size, morphology, zeta-potential

\section{INTRODUCTION}

The simultaneous reduction of natural phosphorus resources available for the phosphate industry, and the increasing awareness of pollution problems such as eutrophication due to phosphorus release in wastewater effluents [1,2], have lead to research into new processes to remove and recover phosphorus from effluents. 
Traditional phosphorus removal processes work by fixing the phosphorus into the sludge:

- either chemically by precipitation of soluble phosphorus with aluminium or iron salts into insoluble phosphates compounds [3];

- or biologically (i.e. BNR, EBPR) using the ability of some micro-organisms to accumulate phosphates as polyphosphates for their own metabolism [4].

Both processes are efficient as they are capable of reducing phosphorus concentration in treated effluents below $1 \mathrm{mg} \mathrm{l}^{-1}$ as required by European legislation [5]. However they lead to accumulation of phosphorus in the sludge as well as an increase in sludge volumes [6].

An approach to remedy these problems and help phosphorus removal from wastewater effluents may be its crystallisation as struvite $\left(\mathrm{MgNH}_{4} \mathrm{PO}_{4} \cdot 6 \mathrm{H}_{2} \mathrm{O}\right)$ [7]. Struvite is more often associated with scaling which affects treatment processes as it leads to operational failures associated to build-up in sludge pipes, centrifuge, heat exchangers and flow-meters $[8,9]$. However, struvite crystallisation, if controlled, represents a promising solution for phosphorus removal and recycling from wastewater effluents. Indeed, as a slow release fertiliser, struvite was proved to be a good source of phosphorus for crops, almost equal in efficiency to mono calcium phosphates, MCP [10]. Furthermore, struvite crystallisation presents other major advantages in that it can help reduce volumes of sludge generated by conventional P-removal processes from $5 \%$ up to $49 \%$ depending on the treatment configuration [11], hence reducing sludge handling costs $[1,7,11]$, and should limit chemical costs which are typically high in metal salt precipitation [1].

In the past ten years, research groups have developed several processes at laboratory or pilot scale, and few at full scale, to study and improve struvite crystallisation from wastewater effluents [12-15]. The processes can be divided in two categories:

- Those which generate struvite particles in stirred or air agitated reactors where crystal growth occurs by interaction between struvite nuclei $[16,17]$ 
- Those which form struvite by crystallisation on seed materials in fluidised bed reactors (FBR) or air agitated reactors. As with the stirred reactors, crystallisation is initiated through chemical addition (i.e. to reach the minimum ratio $\mathrm{Mg}: \mathrm{N}: \mathrm{P}$ 1:1:1 needed) and $\mathrm{pH}$ adjustment but growth is achieved by interaction of nuclei with seeds such as sand or preformed struvite crystals [18, 19].

Although widely studied either at laboratory or pilot scale, struvite crystallisation in a specific reactor located alongside sludge treatment processes remains exceptional at full scale [12]. If most of the time good phosphorus, as well as nitrogen, removals are achieved (i.e. up to 90\% $\mathrm{P}$ removal [20] and up to 95\% $\mathrm{NH}_{4}-\mathrm{N}$ removal [21]), such processes still need improvements especially concerning the control of the quality (size, morphology and purity) and quantity of struvite generated.

The success of struvite crystallisation is governed by various parameters. Among the ones known to be particularly important are $\mathrm{pH}$, magnesium concentration, presence of foreign ions, retention time and presence of seed materials [22-24]. A better understanding on how those parameters can influence the quality of the recovered product is then necessary to maximise phosphorus removal and recovery as struvite.

In the present work, the influence of magnesium concentration, $\mathrm{pH}$, presence of calcium ions and retention time on struvite crystallisation from synthetic liquors was investigated at pilot scale. Experiments particularly focused on how such operating factors could affect purity, size, morphology, and quantity of crystals formed but also the impact they have on phosphorus removal. Zeta-potentials of struvite particles were also measured to investigate if this parameter could be an explanation to overproductions of fine particles. Finally, based on the results achieved, a map of operating conditions which affect (or not) struvite characteristics and $\mathrm{PO}_{4}-\mathrm{P}$ removal was developed in order to identify a set of conditions under which struvite crystallisation was optimised for this system. 


\section{MATERIAL AND METHODS}

Process design and running configurations

A pilot scale crystallisation reactor was designed and developed at Cranfield University to study struvite nucleation and growth on both synthetic and real liquors (Figure 1).

The process was composed of a 101 reactor with two side sampling ports and a drain valve. A peristaltic pump injected simultaneously solutions of ammonium dihydrogen orthophosphate $\left(\mathrm{NH}_{4} \mathrm{H}_{2} \mathrm{PO}_{4} /\right.$ Fisher Analytical Reagent Grade, UK) and magnesium chloride hexahydrate $\left(\mathrm{MgCl}_{2} \cdot 6 \mathrm{H}_{2} \mathrm{O} /\right.$ Fisher analytical Reagent Grade, UK), prepared by dissolution of the corresponding solid compounds in deionised water.

Prior to mixing in the reactor, each solution was adjusted to the required $\mathrm{pH}$ value (usually 9, or 8.5 to 10.5 when the influence of $\mathrm{pH}$ on crystallisation was investigated) with sodium hydroxide $(\mathrm{NaOH} 2 \mathrm{~N} /$ Fisher analytical reagent grade, UK) in stirred buckets. Both solutions were then transferred to the reactor. A pH probe was introduced in the reaction zone to control and maintain the $\mathrm{pH}$ constant during the crystallisation process. An upward air-flow and a liquid recirculation were used and adjusted (5 to $101 \mathrm{~min}^{-1}$ for air, and 1.35 to $1.51 \mathrm{~min}^{-1}$ for liquid) to ensure mixing and growth of the particles formed, and that they were always kept in suspension during the experiment.

The influence of water chemistry on struvite nucleation and growth was investigated by testing different magnesium concentrations ranging from 1.2 to $2.3 \mathrm{mM}$, in a molar ratio Mg:N:P 1:2:2 at $\mathrm{pH}$ 9. The impact of the $\mathrm{pH}$ of precipitation was investigated at the constant magnesium concentration of $1.64 \mathrm{mM}$, whilst keeping the $\mathrm{pH}$ constant in the reactor. The $\mathrm{pH}$ values tested were $8.5,9,9.5,10$ and 10.5 . 
Finally, for the experiments investigating the impact of foreign ions such as calcium, various amounts of calcium chloride dihydrate $0.4 \mathrm{M}\left(\mathrm{CaCl}_{2} .2 \mathrm{H}_{2} \mathrm{O}\right.$ / Fisher Chemicals, UK) were injected in the bucket containing the $\mathrm{MgCl}_{2} \cdot 6 \mathrm{H}_{2} \mathrm{O}$ solution, whilst carbonate ions were added in the ammonium phosphate solution as sodium hydrogen carbonate $0.4 \mathrm{M}\left(\mathrm{NaHCO}_{3} /\right.$ AnalaR Fisher Chemicals, UK) to provide alkalinity so that the solutions were a better analogue to real media (i.e. wastewater effluents/sludge liquors). The experiments were carried out at constant $\mathrm{Mg}$ concentration (i.e. $1.64 \mathrm{mM}$ ) and constant $\mathrm{pH}$ (i.e. 9). The molar ratios $\mathrm{Mg}: \mathrm{Ca}: \mathrm{CO}_{3}$ investigated were 2:1:1, 1:1:1 and 1:2:2.

All standard experiments were conducted at room temperature over 60 minutes, except for the experiments testing the influence of retention time on crystal growth for which experiments were carried out over $5 \mathrm{~h}$ and $24 \mathrm{~h}$ representing the minimum and maximum retention time of struvite crystals in a full scale reactor scenario and as such were appropriate to investigate crystal growth for the specific application described here (Table 1). Each set of experiment was repeated three times.

During experiments, samples could be withdrawn for analysis from sampling ports situated on the side of the reactor at chosen height: top and bottom of the narrower part of the reactor and middle of the enlarged section (Figure 1). Struvite crystal recovery was achieved through a drain valve situated at the bottom of the reactor.

Chemical analysis and crystal characterisation 
After filtration through $0.2 \mu \mathrm{m}$ filters of 21 samples taken at the end of each run, solutions were kept for ICP analysis (Inductively Coupled Plasma Emission Spectroscopy) to determine the remaining magnesium $(\mathrm{Mg})$ and calcium $(\mathrm{Ca})$ concentrations, while phosphate $\left(\mathrm{PO}_{4}-\mathrm{P}\right)$ and ammonium $\left(\mathrm{NH}_{4}-\mathrm{N}\right)$ levels were determined using Merck cell tests.

\section{Particle size analysis}

For each set of experiments, the average size $\left(\mathrm{d}_{0.5}\right)$ of particles was determined using laser diffraction (Mastersizer 2000, Malvern Instrument, UK). To assess the representative average size of particles in the overall reactor, 11 samples were taken from each sampling port, and the drain valve. The average size of particles in the overall reactor was then calculated from the four $\mathrm{d}_{0.5}$ determined at each outlet. Changes in particle size were followed for a range of initial $\mathrm{Mg}$ concentrations, and at constant $\mathrm{Mg}$ concentrations but under different constant precipitation $\mathrm{pH}$. To limit the effect of particle breakage, the peristaltic pump injecting the solution through the Mastersizer cell was set at $40 \mathrm{rpm}$.

\section{Zeta-potential}

The zeta-potential of suspended struvite particles was determined using a Zetasizer 2000 HSA (Malvern Instrument, UK).

\section{Crystalline properties}

Solid residues from 21 filtrations were dried at room temperature and weighed to estimate the rate of struvite production in $\mathrm{mg}^{\mathrm{l}^{-1}}$. Dried samples were then characterised using a Scanning Electron Microscope coupled with Energy Dispersive X-ray Spectroscopy (SEM-EDS, 
Scanning Electron Microscope XL 30 SFEG, Philips, The Netherlands) and X-ray Diffraction (XRD, Powder X-ray Diffractometer D5005, Siemens, Germany) tools.

\section{RESULTS AND DISCUSSION}

Performance of the designed reactor in removing $\mathrm{PO}_{4}-\mathrm{P}$ under various conditions

The first series of experiments aimed at assessing the influence Mg concentrations have on $\mathrm{PO}_{4}-\mathrm{P}$ removal (Figure 2, a). At a constant $\mathrm{pH}$ of 9, and a Mg:N:P ratio of 1:2:2, it was found that varying the range of magnesium concentration tested, from $1.2 \mathrm{mM}$ to $2.3 \mathrm{mM}$, the $\mathrm{PO}_{4}-\mathrm{P}$ removals remained quasi constant with an average value of $77 \pm 4 \%$. $\mathrm{NH}_{4}-\mathrm{N}$ removals measured on the same samples were between $39 \%$ and $56 \%$.

In the presence of calcium ions (Figure 2, b), the remaining concentration of calcium in solution was also recorded to detect the potential removal of calcium as calcium phosphate. In a previous laboratory scale study [22], it was demonstrated that for Ca:Mg molar ratios 1:1 and above, struvite formation was inhibited due to the precipitation of an amorphous calcium phosphate. Here, for a molar ratio Mg:Ca 2:1, the $\mathrm{PO}_{4}-\mathrm{P}$ removal was about the same as without calcium in solution, but a $44 \%$ calcium removal was achieved while less ammonium was removed, indicating that at this $\mathrm{Mg}: \mathrm{Ca}$ molar ratio phosphate ions reacted not only with ammonium and magnesium to form struvite but also with calcium. For molar ratios Mg:Ca 1:2, the $\mathrm{PO}_{4}-\mathrm{P}$ removal increased up to $88 \%$ while a calcium removal of $89 \%$ was also measured but the ammonium removal dropped to below $20 \%$. These results suggest that under these specific conditions, calcium ions can limit struvite crystallisation. 
To assess the impact $\mathrm{pH}$ had on $\mathrm{PO}_{4}-\mathrm{P}$ removal, experiments were performed at a selected constant $\mathrm{pH}$ ranging from 8.5 to 10.5. Results are presented on Figure 2, c. Over the range of $\mathrm{pH}$ tested, good $\mathrm{PO}_{4}-\mathrm{P}$ removals were achieved with values between $75 \%$ at $\mathrm{pH} 8.5$ and $80 \%$ at $\mathrm{pH} 10$. However, analysis of the residual $\mathrm{NH}_{4}-\mathrm{N}$ and $\mathrm{Mg}$ indicated that if maximum ammonium removals were achieved for $\mathrm{pH} 9$ and 9.5 with respective values of $56 \%$ and $59 \%$, it was not the case for magnesium. Indeed, levels of magnesium measured in solution after $1 \mathrm{~h}$ experiment increased over the range of $\mathrm{pH}$ tested with removals varying from $46 \%$ at $\mathrm{pH} 8.5$ up to $92 \%$ at $\mathrm{pH}$ 10.5. $\mathrm{pH} 9$ and 9.5 are the conditions identified here at which struvite crystallisation is optimised with regard to nutrients removal.

Finally the influence of retention time on nutrient removal was also evaluated. A series of experiments were performed at $\mathrm{pH}$ 9, and magnesium concentration $1.64 \mathrm{mM}$ but for the following contact times $1 \mathrm{~h}, 5 \mathrm{~h}$ and $24 \mathrm{~h}$. The results revealed that retention did not affect significantly the amount of $\mathrm{PO}_{4}-\mathrm{P}, \mathrm{NH}_{4}-\mathrm{N}$ and $\mathrm{Mg}$ removed (Figure 2, $\mathrm{d}$ ) as good removals were achieved after only $1 \mathrm{~h}$ of experiment $\left(79 \%, 56 \%\right.$ and $70 \%$ for respectively $\mathrm{PO}_{4}-\mathrm{P}, \mathrm{NH}_{4}-\mathrm{N}$ and Mg).

Impact of operation conditions on struvite characteristics and production

The principal interest of recycling phosphorus from wastewater effluents as struvite is its potential reuse as a fertiliser. Therefore, the efficiency of any reactor does not only depend on phosphorus removal from effluents but also on the quality (i.e. size, morphology and purity) of the final product. It is thus necessary to understand how parameters such as water chemistry, $\mathrm{pH}$, foreign ions, and retention time can affect struvite characteristics. 
For the majority of experiments, conditions of operation have not affected the quality of struvite formed with regard to morphology and purity. Typical orthorhombic crystals were effectively observed (Figure 3, a), except for experiments undertaken in the presence of calcium or at $\mathrm{pH} 10.5$.

In presence of calcium, SEM-EDS and XRD analysis of the recovered products showed no more struvite was observed for ratios 1:1 and above but an amorphous calcium phosphate confirming that high phosphorus removal previously showed (Figure 2, b) were due to the reaction of calcium ions with phosphates.

At $\mathrm{pH}$ 10.5, SEM pictures revealed that struvite crystals were still present, but surrounded by a large amount of a separate phase forming larger plate-like crystals (Figure 3, b).

While XRD analysis undertaken on the recovered products validated that all other samples were pure struvite, the XRD diagram of the product generated at $\mathrm{pH} 10.5$ (not shown) confirmed the presence of a second crystalline compound characterised by two sharp peaks situated at 2-theta angles of $22.319^{\circ}$ and $28.037^{\circ}$. By comparison with XRD reference patterns [25], it was found that most of the peaks matched with the reference pattern for struvite while the two new peaks corresponded to a magnesium phosphate hydrate of chemical formula: $\mathrm{Mg}_{3}\left(\mathrm{PO}_{4}\right)_{2} \cdot 22 \mathrm{H}_{2} \mathrm{O}$, which is known as a synthetic polytype of the cattiite [26]. $\mathrm{Mg}_{3}\left(\mathrm{PO}_{4}\right)_{2} \cdot 22 \mathrm{H}_{2} \mathrm{O}$ usually precipitates at pH 9 and above, and was mentioned previously by Tünay et al. [27] as a compound susceptible to interfere in struvite precipitation depending on process conditions. 
To describe the quality of the recovered product, the mean size $\left(\mathrm{d}_{0.5}\right)$ of particles formed was also assessed. No correlation was found to link the magnesium concentration or the retention time with the size of struvite crystals formed. For instance, values ranged from $48.73 \pm$ $0.58 \mu \mathrm{m}$ to $69.36 \pm 10.24 \mu \mathrm{m}$ over the range of magnesium concentrations $1.2 \mathrm{mM}-2.3 \mathrm{mM}$. For a magnesium concentration of $1.64 \mathrm{mM}$, the average particle size was the highest determined with a mean value of $69.36 \pm 10.24 \mu \mathrm{m}$ (Figure 4 , a).

After $1 \mathrm{~h}, 5 \mathrm{~h}$ and $24 \mathrm{~h}, \mathrm{~d}_{0.5}$ were $69.4 \pm 10.2 \mu \mathrm{m}, 48.6 \pm 7.7 \mu \mathrm{m}$ and $54.3 \pm 2.5 \mu \mathrm{m}$ respectively, showing retention times had little effect here on struvite crystal size, though $\mathrm{pH}$ did have a significant impact on the size of the particles formed. An increase in $\mathrm{pH}$ from 8.5 to 10 linearly decreased the size of crystals formed from $84.0 \pm 11.0 \mu \mathrm{m}$ down to $33.5 \pm 0.7 \mu \mathrm{m}$ (Figure 4, b). However, this decrease in size was not observed at $\mathrm{pH} 10.5$, for which the average particle size recorded was $79.0 \pm 0.7 \mu \mathrm{m}$. But in that situation, the increase in size was not related to struvite, but to the presence of $\mathrm{Mg}_{3}\left(\mathrm{PO}_{4}\right)_{2} \cdot 22 \mathrm{H}_{2} \mathrm{O}$ as it was found to be the main compound formed at this $\mathrm{pH}$. Those results are consistent with the one observed by Matynia et al., [23] in their study of the influence of process parameters on struvite crystallisation kinetics where they reported that an increase of $\mathrm{pH}$ from 8 to 10 resulted in a significant decrease in struvite crystal size (i.e. a 5.5-fold decrease). However, for a $\mathrm{pH}$ of 11, Matynia et al. [23] still observed a decrease in particle size, while in the present study, the size of particles recorded at a $\mathrm{pH}$ of 10.5 increased significantly.

Finally, no significant changes in size were observed between the samples taken from the different sampling port situated on the side of the reactor indicating a homogeneous mixing keeping the particles in suspension. But this also suggests that the growth was limited as particles taken from the drain valve should have been bigger due to settlement. 
While size is important to facilitate struvite recovery, and purity is essential for reuse as a fertiliser, quantity is crucial to the economical viability of the process. The amount of struvite recovered has been quantified for each specific condition of precipitation previously tested (Figure 5).

For experiments undertaken with varying $\mathrm{Mg}$ concentrations the production increased as expected, as more $\mathrm{Mg}$ was available to form struvite. To illustrate, $75 \mathrm{mg} \mathrm{l}^{-1}$ and $375 \mathrm{mg} \mathrm{l}^{-1}$ of struvite were recovered when the respective $\mathrm{Mg}$ concentrations were $1.2 \mathrm{mM}$ and $2.3 \mathrm{mM}$.

$\mathrm{pH}$ had a significant effect on quantity of product formed with the average mass of struvite in the reactor ranging from 290.1 to $345 \mathrm{mg} \mathrm{l}^{-1}$ between $\mathrm{pH} 9$ and 10, while at $\mathrm{pH} 8.5$ struvite quantities observed were low $\left(171.3 \mathrm{mg} \mathrm{l}^{-1}\right)$ when compared to those at higher $\mathrm{pH}$ (Figure 5, a).

Similar explanations are attributed to high rates of production observed in presence of high levels of calcium (Figure 5, b). By addition of calcium in a molar ratio Mg:Ca 2:1, less product was formed: $217.9 \mathrm{mg} \mathrm{l}^{-1}$ instead of $302.2 \mathrm{mg} \mathrm{l}^{-1}$ without any calcium. It shows at this particular Mg:Ca molar ratio that calcium partly inhibited struvite formation while calcium phosphate occurrence remained too low to affect the overall mass of product formed. For molar ratio Ca:Mg 1:1 and above a significant increase of the mass of product recovered per litre was observed. Rates reached values of $400.0 \mathrm{mg}^{-1}$ and more (Figure 5, b). As seen previously at this stage, this increase is not attributed to the formation of struvite but to the additional production of calcium phosphate.

Finally, retention time had no major effects on production rate with an average value of $265.1 \pm 32.7 \mathrm{mg} \mathrm{l}^{-1}$ over the range of times trialled (Figure 5, c). 
In his economic evaluation of phosphorus recovery as struvite from digester supernatant, Shu et al. [1] estimated that a WWTP treating $100 \mathrm{~m}^{3} \mathrm{~d}^{-1}$ of wastewater can reasonably recover $1 \mathrm{~kg}$ of struvite. In the current study, at constant $\mathrm{pH} \mathrm{9,} \mathrm{for} \mathrm{a} \mathrm{concentration} \mathrm{of}$ magnesium of $1.64 \mathrm{mM}$, and a molar ratio Mg:N:P 1:2:2, $290.1 \mathrm{mg} \mathrm{l}^{-1}$ of struvite were recovered. Theoretically, $100 \mathrm{~m}^{3}$ of the identical synthetic liquors would then produce $29 \mathrm{~kg}$ of struvite. However the present tests were carried out in batch mode. Taking into account that 91 of solution per hour were needed to produce $2.61 \mathrm{~g}$ of struvite, the present reactor could then only treat $0.216 \mathrm{~m}^{3}$ per day. A scaling up of the reactor's volume, and adaptation of this latest to a continuous mode would be thus necessary to achieve a struvite production of $29 \mathrm{~kg}$ per $100 \mathrm{~m}^{3}$ of identical wastewaters.

\section{Limitations of the process}

This first series of experiments testing different conditions of precipitation at pilot scale in the designed reactor has demonstrated limitations for the process. Even though most of the time good phosphorus removals were achieved and reasonable quantities of pure struvite were reached, growth was limited with final particle size $\left(\mathrm{d}_{0.5}\right)$ rarely exceeding $100 \mu \mathrm{m}$ after $1 \mathrm{~h}$ of experiments. However, comparison with the literature showed that particle sizes observed here can be similar, and sometimes greater than struvite crystal sizes generally observed (Table 2).

For example, Kofina and Koutsoukos [28] crystallised struvite from synthetic wastewaters at laboratory scale and did not form crystals over $30 \mu \mathrm{m}$ after $1 \mathrm{~h}$ of experiments. Conversely, in their pilot scale study of phosphorus recovery by struvite crystallisation, Adnan et al. [31], managed to form crystals of $2.5 \mathrm{~mm}$ average size but only after a minimum of 7 days in their pilot-scale fluidised bed reactor. 
In systems precipitating struvite from real media (i.e. anaerobically digested sludge liquors, Table 2), struvite crystal sizes vary a lot from one type of reactor to another. This is mainly due to differences in operating conditions, especially crystal retention time, and probably to variations in quantities of impurities in liquors. To illustrate, Von Münch and Barr [32] achieved mean crystal sizes of $110 \mu \mathrm{m}$ after $24 \mathrm{~h}$ of operation in a pilot scale air agitated reactor, while Ueno and Fujii [12] generated crystals between 500 and $1000 \mu \mathrm{m}$ after 10 days at full scale.

Nevertheless, comparisons of particle size can be difficult as sizes of struvite crystals strongly depends on the morphology of the product. For instance, Stratful et al. [29] indicated that they formed crystals of $3 \mathrm{~mm}$ mean size, but in that case crystals were thin and elongated, while Adnan et al. [31] formed comparable particles in size, which, however, were shown by microscopy to be agglomerates of single crystals. For an efficient recovery or ease of reuse, agglomerated particles are ideal. Indeed, individual elongated crystals are fragile, and would increase settlement stages when compared to agglomerated crystals. However, the causes of struvite crystal agglomeration are unclear [31]. A small variation in nature of feed, operating $\mathrm{pH}$, and supersaturation, can have a major impact on growth, hence leading to big changes in struvite morphology.

Given that an excess formation of small crystals was observed in all sets of experiments, the possible influence of zeta-potential on struvite growth through agglomeration was then investigated.

Zeta-potential measurements undertaken on struvite suspensions generated in the pilot reactor demonstrated that when the $\mathrm{pH}$ of precipitation increased from 8.5 to 10, average size of particles dropped from 80 down to $33 \mu \mathrm{m}$ while associated zeta-potentials decreased from -17.5 \pm 1.1 to $-23.3 \pm 0.6 \mathrm{mV}$ (Table 3). At $\mathrm{pH} \mathrm{10.5,} \mathrm{the} \mathrm{zeta-potential} \mathrm{was} \mathrm{the} \mathrm{lowest} \mathrm{value} \mathrm{recorded}$ 
but the associated size of particles increased significantly up to $79 \mu \mathrm{m}$. Nevertheless, this deviation could be due to the fact that at this $\mathrm{pH}$ both struvite and $\mathrm{Mg}_{3}\left(\mathrm{PO}_{4}\right)_{2} \cdot 22 \mathrm{H}_{2} \mathrm{O}$ were formed.

Struvite zeta-potential was first reported by Bouropoulos and Koutsoukos [33]. They indicated that struvite particle charge may have an influence on its agglomerative properties. As also demonstrated here, they found that the charge of struvite particles formed varied with $\mathrm{pH}$, and that struvite particles had higher zeta-potential at higher $\mathrm{pH}$ of crystallisation (Table 3). Although they did not link those values to particle size, they mentioned that such variations in zeta-potential were likely to have an effect on crystal growth kinetics and lead to eventual destabilisation of particles by aggregation. Finally they remarked that an increase in $\mathrm{pH}$ above 10.5 caused visible flocculation of crystals, which could correlate with the precipitation of $\mathrm{Mg}_{3}\left(\mathrm{PO}_{4}\right)_{2} .22 \mathrm{H}_{2} \mathrm{O}$ observed here at the same $\mathrm{pH}$ of crystallisation.

Experiments undertaken here showed that zeta-potential is another parameter that could influence struvite crystal characteristics. A small difference of $\mathrm{pH}$ can effectively cause a variation in zeta-potential, affecting thus struvite surface charge. According to zeta-potential values measured, struvite particles precipitated under the current operating conditions were kept apart due to electrostatic repulsions [34]. This phenomenon limited their tendency to attract each other and their subsequent growth through agglomeration. This may explain why only single crystals of struvite have been observed in this study.

\section{CONCLUSION}

The operation of a pilot scale reactor under a range of conditions of precipitation in which variables such as water chemistry, presence of foreign ions, $\mathrm{pH}$ of precipitation and 
reaction times were tested, showed its capacity to remove high amounts of phosphorus $(\sim 80 \%$ at constant $\mathrm{pH}$ 9) after rather short experimental times (1 hour). It was shown (Figure 6) that $\mathrm{pH}$ was the most influential parameter as it affects nutrient removal, quantity of product formed, and quality (i.e. size, morphology and purity) of the crystallised struvite, while foreign ions mainly affect quality of the product formed and $\mathrm{PO}_{4}-\mathrm{P}$ removal. Magnesium concentrations and experimental times had the least effect, with magnesium affecting only quantity of struvite formed while experimental time affected neither struvite characteristics nor nutrient removal.

However, the process showed limits with regards to the size of particles formed as an overproduction of small particles was observed. A possible explanation to this could come from the actual surface charge of struvite crystals. Negative zeta-potential of struvite particles demonstrated here indicated that agglomeration processes were not favoured. Possible solutions to remedy this problem of fines formation could be:

- the coagulation of fine particles by addition of positively charged compounds into struvite solutions to initiate agglomeration.

- the utilisation of seed particles, such as sand, or preformed struvite crystals, which could effectively help to improve the growth step, as they would enable the agglomeration of struvite fine particles on those materials.

Both solutions were investigated and will be the object of future publications.

\section{ACKNOWLEDGEMENTS}

The authors would like to thank Cherub and Severn Trent Water for their sponsorship of this work. The authors would also like to thank Caroline Kirk from The Natural History Museum, London, for the final identification of the magnesium phase as a synthetic polytype of cattiite, $\mathrm{Mg}_{3}(\mathrm{PO} 4)_{2} \cdot 22 \mathrm{H}_{2} \mathrm{O}$. 


\section{REFERENCES}

1. Shu L., Schneider P., Jegatheesan V. and Johnson J., An economic evaluation of phosphorus recovery as struvite from digester supernatant. Bioresource Technol., 97, 2211-2216 (2006).

2. UWWTP. Council of the European Communities., Council directive of 21 may 1991 concerning urban waste water treatment (91/271/EEC). Official Journal L, 135/40 (1991).

3. Donnert D. and Salecker M., Elimination of phosphorus from municipal and industrial wastewater. Water Sci. Technol., 40, 195-202 (2001).

4. Mulkerrins D., Dobson A.D.W. and Colleran, E. Parameters affecting biological phosphate removal from wastewaters. Environ. Int., 30, 249-259 (2004).

5. Booker N.A., Priestley A.J. and Fraser I.H., Struvite formation in wastewater treatment plants: opportunities for nutrient recovery. Environ. Technol., 20, 777-782 (1999).

6. Woods N.C., Sock S.M. and Daigger G.T., Phosphorus recovery technology modelling and feasibility evaluation for municipal wastewater treatment plants. Environ. Technol., 20, 663-679 (1999).

7. Doyle J.D. and Parsons S.A., Struvite formation, control and recovery. Water Res., 36, 39253940 (2002). 
8. Doyle J.D. and Parsons S.A., Struvite scale formation and control. Water Sci. Technol., 49, 177$182(2004)$.

9. Neethling J.B. and Benisch M., Struvite control through process and facility design as well as operation strategy. Water Sci. Technol., 49, 191-199 (2004).

10. Johnston A.E. and Richards I.R., Effectiveness of different precipitated phosphates as phosphorus sources for plants. Soil Use Manage., 19, 45-49 (2003).

11. Woods N.C., Daigger G.T. and Sock S.M., Sewage sludge reductions offered by phosphate recycling. CHIMICA Oggi/Chemistry today (2000).

12. Ueno Y. and Fujii M., Three years experience of operating and selling recovered struvite from full-scale plant. Environ. Technol., 22, 1373-1381 (2001).

13. Wu Q. and Bishop P.L., Enhancing struvite crystallisation from anaerobic supernatant. J. Environ. Eng. Sci., 3, 21-29 (2004).

14. Battistoni P., Paci B., Fatone F. and Pavan P., Phosphorus removal from supernatants at low concentration using packed and fluidised-bed reactors. Ind. Eng. Chem. Res., 44, 6701-6707 (2005).

15. Suzuki K., Tanaka Y., Kuroda K., Hanajima D., and Fukumoto Y., Recovery of phosphorus from swine wastewater through crystallization. Bioresource Technol., 96, 1544-1550 (2005). 
16. Jaffer Y. and Pearce P., Phosphorus recovery via struvite production at Slough sewage treatment works, UK-a case study. In: Phosphorus in Environmental technologies. Principles and applications, Valsami-Jones E. (ed.), IWA publishing, London, pp. $402-427$ (2004).

17. Fujimoto N., Mizuochi T. and Togami Y., Phosphorus fixation in the sludge treatment system of a biological phosphorus removal process. Water Sci. Technol., 23, 635-640 (1991).

18. Battistoni P., Pavan P., Cecchi F. and Mata-Alvarez J., Phosphate removal in real anaerobic supernatants: modelling and performance of a fluidized bed reactor. Water Sci. Technol., 38, 275283 (1998).

19. Ohlinger K.N., Young T.M. and Schroeder E.D., Postdigestion struvite precipitation using a fluidised bed reactor. J. Environ. Eng., 126, 361-368 (2000).

20. Ishikawa H., Shimamura K., Sawai K., and Tanaka T., A 2-tank type fluidised bed MAP crystallisation reactor for effective phosphorus recovery. In: Proc. of the Int. Conf. on struvite: its role in phosphorus recovery and reuse, Cranfield, UK, (June 2004).

21. Uludag-Demirer S., Demirer G.N. and Chen S., Ammonia removal from anaerobically digested dairy manure by struvite precipitation. Process Biochem., 40, 3667-3674 (2005).

22. Le Corre K.S., Valsami-Jones E., Hobbs P. and Parsons S.A., Impact of calcium on struvite crystal size, shape and purity. J. Cryst. Growth, 283, 514-522 (2005). 
23. Matynia A., Koralewska J., Wierzbowska B. and Piotrowski K., The influence of process parameters on struvite continuous crystallisation kinetics. Chem. Eng. Commun., 193, 160-176, (2006).

24. Wang J., Burken J.G. and Zhang X., Effect of seeding materials and mixing strength on struvite precipitation. Water Environ. Res., 78, 125-132 (2006).

25. Mineral database PCPDFWIN version1.3.

26. Britvin S.N., Ferraris G., Ivaldi G., Bogdanova A.L., and Chukanov N.V., Cattiite, $\mathrm{Mg}_{3}\left(\mathrm{PO}_{4}\right)_{2} .22 \mathrm{H}_{2} 0$, a new mineral from Zheleny Mine (Kovdor Massif, Kolapeninsula, Russia). $N$. Jb. Miner. Mh., 4, 160-168 (2002).

27. Tünay O., Kabdasli I., Ohron D. and Kolçak S., Ammonia removal by magnesium ammonium phosphate precipitation in industrials wastewaters. Water Sci. Technol., 36, 225-228 (1997).

28. Kofina A.N. and Koutsoukos P.G., Spontaneous precipitation of struvite from synthetic wastewater solutions. Cryst. Growth Des., 5, 489-496 (2004).

29. Stratful I., Scrimshaw M.D. and Lester J.N., Conditions influencing the precipitation of magnesium ammonium phosphate. Water Res., 35, 4191-4199 (2001). 
30. Stratful I., Scrimshaw M.D. and Lester J.N., Removal of struvite to prevent problems associated with its accumulation in wastewater treatment works. Water Environ. Res., 76, 4374199 (2004).

31. Adnan A., Mavinic D.S. and Koch F.A., Pilot-scale study of phosphorus recovery through struvite crystallization-examining the process feasibility. J. Environ. Eng. Sci., 2, 315-324 (2003).

32. Von Münch E. and Barr K., Controlled crystallisation for removing phosphorus from anaerobic digester side stream. Water Res., 35, 151-159 (2001).

33. Bouropoulos N.Ch. and Koutsoukos P.G., Spontaneous precipitation of struvite from aqueous solutions. J. Cryst. Growth, 213, 381-388 (2000).

34. Duan J. and Gregory J., Coagulation by hydrolysing metal salts. Adv. Colloid Interfac., 100102, 475-502 (2003). 
List of acronyms

BNR Biological Nutrient Removal

EBPR Enhanced Biological Phosphorus Removal

FBR Fluidised Bed Reactor

ICP Inductively Coupled Plasma Emission Spectroscopy

MCP Mono Calcium Phosphate

Rpm Rotation Per Minute

RT Retention Time

SEM-EDS Scanning Electron Microscope- Energy dispersive X-ray Spectroscopy

XRD X-Ray Diffraction

WWTP Waste Water Treatment Plant 


\section{List of Figures}

Figure 1. Pilot scale unit.

Figure 2. Effect of $\mathrm{Mg}$ concentration, calcium, $\mathrm{pH}$ and retention time on $\mathrm{PO}_{4}-\mathrm{P}, \mathrm{NH}_{4}-\mathrm{N}$ and Mg removals.

Figure 3. SEM pictures of typical struvite crystals (a) and sample recovered at $\mathrm{pH} 10.5$ (b).

Figure 4. Average size of particles formed in the reactor as a function of $\left[\mathrm{Mg}^{2+}\right]$, and $\mathrm{pH}$.

Figure 5. Effect of $\mathrm{pH}$, calcium ions, and retention time on struvite production.

Figure 6. Overview of operating parameters' impact on struvite crystallisation.

\section{List of Tables}

Table 1. Experimental matrix.

Table 2. Struvite crystal sizes reported in the literature.

Table 3. Average struvite crystal sizes and respective zeta-potentials at different $\mathrm{pH}$ of crystallisation. 
Table 1. Experimental matrix.

\begin{tabular}{|c|c|c|c|c|c|c|}
\hline & & \\
\hline & & Experiment & $\begin{array}{c}\mathrm{Mg} \\
\text { dose } \\
(\mathrm{mM})\end{array}$ & $\mathrm{pH}$ & $\begin{array}{l}\text { Retention } \\
\text { time } \\
\text { (h) }\end{array}$ & $\begin{array}{c}\mathrm{Mg}: \mathrm{Ca} \\
\text { ratio }\end{array}$ \\
\hline \multirow{15}{*}{$\begin{array}{c}\text { Parameter } \\
\text { investigated }\end{array}$} & \multirow{3}{*}{ Mg dose } & \multirow{3}{*}{$-a-$} & 1.2 & \multirow{3}{*}{9} & \multirow{3}{*}{1} & \multirow{3}{*}{-} \\
\hline & & & 1.64 & & & \\
\hline & & & $\begin{array}{c}1.96 \\
2.3\end{array}$ & & & \\
\hline & \multirow{4}{*}{$\begin{array}{l}\text { Calcium } \\
\text { dose }\end{array}$} & \multirow{4}{*}{$-b-$} & \multirow{4}{*}{1.64} & \multirow{4}{*}{9} & \multirow{4}{*}{1} & $1: 0$ \\
\hline & & & & & & $2: 1$ \\
\hline & & & & & & $1: 1$ \\
\hline & & & & & & $1: 2$ \\
\hline & \multirow{5}{*}{$\mathrm{pH}$} & \multirow{5}{*}{$-c-$} & & 8.5 & \multirow{5}{*}{1} & \multirow{5}{*}{-} \\
\hline & & & & 9 & & \\
\hline & & & 1.64 & 9.5 & & \\
\hline & & & & 10 & & \\
\hline & & & & 10.5 & & \\
\hline & \multirow{3}{*}{$\begin{array}{l}\text { Retention } \\
\text { time }\end{array}$} & \multirow{3}{*}{$-\mathrm{d}-$} & \multirow{3}{*}{1.64} & \multirow{3}{*}{9} & 1 & \multirow{3}{*}{-} \\
\hline & & & & & 5 & \\
\hline & & & & & 24 & \\
\hline
\end{tabular}


Table 2. Struvite crystal sizes reported in the literature.

\begin{tabular}{|c|c|c|c|c|}
\hline Media & Type of reactor & $\begin{array}{l}\text { Running } \\
\text { Time }\end{array}$ & $\begin{array}{l}\text { Particle } \\
\text { size } \\
(\mu \mathrm{m}) \\
\end{array}$ & References \\
\hline \multirow{4}{*}{$\begin{array}{c}\text { Synthetic } \\
\text { wastewaters }\end{array}$} & $\begin{array}{c}\text { Stirred reactor } \\
V=0.61\end{array}$ & $15 \mathrm{~min}$ & $5.6-45.6$ & [23] \\
\hline & $\begin{array}{c}\text { Stirred reactor } \\
\quad V=0.251\end{array}$ & 25 to $90 \mathrm{~min}$ & $10-30$ & [28] \\
\hline & $\begin{array}{l}\text { Stirred reactors } \\
\qquad V=21\end{array}$ & 5 days & $425-2360$ & {$[29,30]$} \\
\hline & $\begin{array}{c}\text { Fluidised Bed } \\
\mathrm{V}=24.41\end{array}$ & 7 to 17 days & $2600-3700$ & [31] \\
\hline \multirow{3}{*}{$\begin{array}{c}\text { Anaerobically } \\
\text { digested } \\
\text { sludge } \\
\text { liquors }\end{array}$} & $\begin{array}{c}\text { Air agitated } \\
\text { reactor } \\
\mathrm{V}=3.51\end{array}$ & A few days & 300 & [16] \\
\hline & $\begin{array}{c}\text { Air agitated } \\
\text { column reactor } \\
\mathrm{V}=1431\end{array}$ & 1 day & $25-215$ & [32] \\
\hline & $\begin{array}{l}\text { Fluidised bed } \\
\text { reactor } \\
\mathrm{V}>25 \mathrm{~m}^{3}\end{array}$ & 10 days & $500-1000$ & [12] \\
\hline
\end{tabular}


Table 3. Average struvite crystal sizes and respective zeta-potentials at different $\mathrm{pH}$ of crystallisation.

\begin{tabular}{cccc}
\hline & Present study & & $\begin{array}{c}\text { Bouropoulos and } \\
\text { Koutsoukos, [33] }\end{array}$ \\
\hline $\mathrm{pH}$ & Zeta-potential $(\mathrm{mV})$ & Size $(\mu \mathrm{m})$ & $\begin{array}{c}\text { Zeta-potential }(\mathrm{mV}) \\
(\text { estimated from graph })\end{array}$ \\
\hline 8.5 & $-17.5 \pm 1.1$ & $84.0 \pm 11.2$ & - \\
9.0 & $-20.4 \pm 2.4$ & $69.4 \pm 10.2$ & - \\
9.5 & $-23.1 \pm 1.4$ & $40.1 \pm 10.3$ & $\sim-21.5$ \\
10.0 & $-23.3 \pm 0.6$ & $33.5 \pm 0.7$ & $\sim-25.5$ \\
10.5 & $-27.6 \pm 1.2$ & $79.0 \pm 7.8$ & - \\
\hline
\end{tabular}

